\title{
Pricing research and development services in the USSR *
}

\author{
Morris BORNSTEIN \\ Department of Economics, The University of Michigan, Ann Arbor, MI 48109, USA
}

Final version received October 1983

Most Soviet applied research and development (R\&D) is performed by organizations of industrial branch ministries. Pricing of applied R\&D begins with calculations of costs, which are often inflated. Soviet specialists disagree on whether R\&D prices should include a profit above cost, and, if so, how the profit should be determined. Current pricing schemes for applied R\&D include profits based on planned wage cost, on planned total cost, or on the economic effect of the R\&D.

The use of the last pricing method is analyzed and evaluated in detail. In principle this method creates incentives for timely delivery of high quality $R \& D$ results suitable for assimilation into production. However, in practice the strength of these incentives is considerably weakened by a number of factors.

\section{Introduction}

In the USSR prices for research and development (R\&D) services are used in the stages of applied research and development. The earlier stage of fundamental research is not expected to generate a practical result that can be priced, while the later innovation stage is supposed to yield mass production of new products to be sold at industrial wholesale prices.

Of total Soviet applied R\&D, 90-95 percent is performed by research institutes, design bureaus, and other organizations of industrial branch ministries, and 5-10 percent by units of academies of sciences or higher educational institutions [33, pp. 3-4 and 43-46].

Applied $R \& D$ is arranged through a contract

\footnotetext{
* The author wishes to thank the National Council for Sovict and East European Research for financial support for this study; the International Research and Exchanges Board for aid on a research trip to Eastern Europe; John Attarian for his assistance in research; and three anonymous referees for this journal for their helpful suggestions.
}

Research Policy 13 (1984) 85-100

North-I Iolland between the R\&D unit and an enterprise (or a work-order from the branch ministry to the R\&D organization). ${ }^{1}$ R\&D contracts are not usually the result of free choice and initiative on the part of the R\&D performer and the client enterprise about what R\&D is to be done, by whom, and for whom. Instead, the contracts typically are agreements to carry out tasks in official plans for research, development and innovation. There is no practice of competitive bidding by $R \& D$ organizations for contracts. Rather, the R\&D performer and the customer negotiate a mutually acceptable agreement within the framework of plan assignments.

The contract for a particular project covers the technical specifications, the number and types of products (formulas, experimental results, technical drawings, prototypes, etc.), the "guaranteed economic effect" (when this can be calculated), the terms and schedule of compensation, intermediate and final deadlines, procedures for approval and delivery of completed work, penalties for unsatisfactory or late performance, and provisions for revising different aspects of the contract [33, pp. 29-33].

Section 2 of this study explains the costing of applied R\&D projects, and section 3 examines how prices for them are set in relation to costs so determined. Section 4 then analyzes and evaluates $R \& D$ pricing schemes linked to economic effect and intended to motivate $R \& D$ organizations to produce and deliver on time high quality results ready for assimilation into production.

\footnotetext{
1 The terms "contract" and "work-order" distinguish the administrative relationship between the $R \& D$ performer and the customer. However, the two agreements are basically similar in content - i.e. in stating the respective responsibilities of the two parties.
} 


\section{Costing applied research and development services}

Cost calculations for Soviet applied R\& D projects cover (1) wages, (2) social insurance, (3) materials, (4) special equipment, (5) travel, (6) payments to subcontractors, and (7) general overhead expenditures [33, pp. 51-54]. ${ }^{2}$

The wage component alone is commonly at least one-third of the cost of a project of an industrial branch $\mathrm{R} \& \mathrm{D}$ organization. Overhead expenditures constitute about $30-40$ percent of total operating expenses of branch R\&D units, and they are distributed among individual $R \& D$ projects in proportion to wages [48, p. 35].

The sum of planned direct and indirect costs of an R\&D project is its planned "cost of production" that is the basis for the "estimate cost" used in pricing the project. If the price is set equal to the estimate cost, the latter also is the "value" of the project. (Alternative pricc-cost relationships are discussed below in section 3.)

In Soviet applied $\mathrm{R} \& \mathrm{D}$, project costs are usually estimated through comparisons with previous R \& D work deemed "analogous", although there is some effort to base cost estimates on formal "norms".

\subsection{Analog approach}

The analog approach to estimating costs rests on the proposition that there are many common basic elements found in certain quantitative and qualitative relationships in all $\mathrm{R} \& \mathrm{D}$, and that these elements can be identified, analyzed, and costed in terms of the kind and amount of labor, materials, components, and other inputs involved. Under this approach, the R\&D organization selects from its previous projects one or more that are analogous to the new project in purpose, nature of final result, composition of $R \& D$ tasks,

2 This cost classification does not take into account capital investment expenditures for the construction of buildings, for the acquisition and installation of multipurpose equipment, and for capital repair of buildings and equipment. The failure to charge depreciation understates the true cost of $R \& D$ work and also deprives $R \& D$ organizations of a potentially important source of financing new capital investment. Thus. some Soviet specialists urge the introduction of amortization allowances - and at rates much higher than in industry for similar kinds of assets, on the ground that obsolescence is much faster in R\&D than in ordinary production activities $[39$, p. $89 ; 35$, pp. $180-181]$. use of standard components, etc. Analyzing this information, the organization estimates the quantities of the various kinds of inputs required for the new project, the duration of the work, and its cost. Because earlier analogous projects are similar but not identical to the new project, adjustments ("corrections") must be made for differences in the complexity and originality of the new project compared with the analog(s).

In practice the application of the analog approach is limited for two main reasons. One is the extent to which the institute's previous $R \& D$ includes sufficiently close analogs to the new project. When no appropriate analog is identified, the costs of the new project are estimated by "direct calculation" that starts from figures for average expenses per average scheduled worker involved. The second reason - more important according to Soviet specialists - is the lack of sufficiently detailed information on the cost of each of the "basic elements" or "standard tasks" constituting the R\&D process and incorporated in the analog. Thus, use of the analog approach commonly yields only approximate cost estimates, often biased upward for reasons discussed below.

\subsection{Norm approach}

Some Soviet science economists recommend that $R \& D$ cost estimates be based on formal standard cosl "norms" (as in industrial production), rather than on the extrapolation of the R\&D unit's past experience under the analog method [4, pp. 43-58; 26, pp. 115-121]. The R\&D organization would use a set of norms for labor, materials, and other direct costs per unit of "output" - such as an experiment, a group of calculations, a design element, or a set of drawings. In turn the overhead norm would be expressed per 1,000 rubles of direct wages or total direct costs. These norms would be calculated from the past experience of various R\&D organizations over several years, adjusted for the expected reduction in input costs per unit of output in order to obtain "progressive" norms.

However, the use of such cost norms in Sovict R \& D organizations is limited [6, p. 37], and some Soviet science specialists doubt that they can be applied widely. First, data are lacking on unit costs in physical and money terms for the same basic elements of $R \& D$ in different organizations. Second, the originality and uncertainty of $R \& D$ make it difficult to specify how many times a 
particular operation, such as a test or drawing, should be done until a successful result is obtained and the next step in the R\&D process undertaken. Third, a reasonable norm for a task may vary considerably across R\&D units because of the particular individuals involved, their equipment, and the organization and administration of the institute or design bureau. Hence, common norms for various $R \& D$ organizations could be only benchmarks not binding limits, or each organization should have its own individual set of norms. ${ }^{3}$

${ }^{3}$ In addition to these general problems of norm-setting, there are particular issues in establishing norms for individual cost categories.

R\&D organizations of ten overstate labor requirements and wage costs $[8$, p. 91$]$. These costs are a major component - a third to a half - of total costs. Also, materials, travel, and some other costs are frequently estimated on the basis of the number of workers. Finally, overhead costs are related to wage costs. Hence, periodic campaigns press for the reduction of labor costs. However, R\&D organizations respond, for example, by holding down or reducing the average wage through an increase in the proportion of less qualified lowerwage personnel [28, p. 137], and total wages by subcontracting work to other organizations $[7$, p. 70$]$.

Norm-setting for materials and equipment is more difficult and less developed than for labor. Outlays on materials and equipment constituted about 17 percent of total R\&D expenditures (excluding capital investment) in 1976, and the share is growing. About 60 percent of these outlays is for instruments, laboratory equipment, and measuring devices [16, pp. 109-110]. R\&D organizations overstate their requirements for materials and equipment because of their difficulties in obtaining what they need. "Material-technical supply" is a widespread and serious problem in the Soviet economy generally, but there are special features in the case of R\&D. Plans for the supply of materials and equipment to $R \& D$ organizations are not adequately coordinated with their research and financing plans. As a result, supply agencies cannot deliver the materials and equipment needed to carry out the R\&D organizations plans. For example, according to a Soviet science economist, from 1965 to 1976 total outlays on science grew about 150 percent, while the volume of "major" types of materials and equipment provided for scientific purposes increased only $15-20$ percent $[15, p$. 101].Capital investment plans for science emphasize buildings rather than equipment $[20$, p. 58$]$. $R \& D$ organizations have more difficulty than industrial enterprises in obtaining supplies and equipment because a considerable portion of R\&D organizations' requirements are for relatively small amounts (sometimes only grams or kilograms) of high quality items that are hard to estimate accurately 612 months in advance, when supply orders must be submitted $[15$, p. 102]. Recognizing these problems, R\&D organizations try to order larger amounts of materials and equipment than they actually need. To the extent that they are successful in this attempt, the R\&D units then have excess stocks of materials [22, p. 143] and underutilized equipment $[20$, p. 74$]$.
$R \& D$ organizations inflate estimate costs for two rcasons. One is to obtain "insurance" against the financial risks from the uncertainty involved in R \& D [29, p. 144; 21, p. 39]. ${ }^{4}$ The other is to earn a surplus, or profit, to be devoted partly to the R \&D unit's funds for individual bonuses and for housing and recreational activities and partly to the organization's development fund (for research materials, equipment, and facilities) $[13$, p. $61 ; 1$, p. 187]. Both of these reasons can be attributed to the absence of satisfactory arrangements for pricing $R \& D$ services with an explicit profit above cost [7, p. 72].

\section{Prices for applied research and development services}

Soviet methods for pricing R\&D services have evolved in response to - and can be fully understood only in the light of - an extensive theoretical debate among Soviet science economists. This section first explains the theoretical debate and then examines the resulting pricing arrangements.

\subsection{Theoretical debate}

The theoretical debate among Soviet economists about the pricing of $R \& D$ services involves two main questions: (1) Should any $R \& D$ have a price at all? (2) If so, how should the price be set?

\subsubsection{Should R\&D have a price?}

One school of Soviet economists believes that $\mathrm{R} \& \mathrm{D}$ should not be assigned a price because it is not a "commodity" as this concept is understood in Marxian value theory. They argue that R\&D does not meet all three of the following conditions for a "commodity": (1) A "commodity" must have social use value. (2) This value must be measurable in terms of "socially necessary labor costs". (3) The good or service must be transferred to the user through the process of exchange [53, pp. 43-45].

(1) In regard to social use value, this school holds that R\&D is merely a "potential commodity" and can become an "actual commodity" only when it is introduced into production and thus

4 Another way of reducing risk is to revise cost estimates upward during the course of the project. About two-thirds of Soviet R\&D cost estimates are so "corrected" [51, pp. 83-84]. 
"materialized" in industrial output. This view has several implications. First, some R\&D will never be so "materialized", either because it is unsuccessful or because. though successful. the R\&D is not (fully) used by customer enterprises that lack the technical capabilities or the economic incentives to apply it [19, p. 146]. Second, the value and price of successful and adopted R\&D should be measured in the light of the effect from its use in production $[49$, p. 43]. Third, the creation of prototypes might be considered the earliest step in the R\&D process to involve "material production" and thus to qualify as a "commodity" (27, pp. $26-29]$

(2) "Socially necessary labor costs" (SNLC) are the average costs of present labor and past labor (embodied in material inputs and the amount of fixed assets used up as measured by depreciation) in repeated production of a commodity in many enterprises over a period of years. This school believes that because R\&D is supposed to be an original, not a repetitive, activity, it is impossible to calculate SNLC for R\&D and therefore to establish the cost norms discussed above [51, p. $80 ; 23$, p. 139].

(3) The transfer ("alienation") of R\&D through exchange occurs only when $R \& D$ is sold to a particular buyer for a specific price. Applied R\& D under contracts (and work-orders) meets this requirement, but fundamental research is done for and belongs to society as a whole [19, pp, 59-64].

Another school of Soviet economists - of increasing influence, to judge by the amount and promincnce of the publications in which their views are expressed - argues that R\&D is a "commodity" and should have a price for this and other reasons. They rebut each of the three arguments just presented.

(1) They hold that the socially useful properties of $R \& D$ are created in the $R \& D$ process itself and do not depend on the subsequent assimilation of $R \& D$ into the output of material production. Rather, the assimilation stage is considered to involve the "consumption" of the useful properties of (applied) R\&D [39, pp. 25-26]. Thus, there is a clear parallel, for example, with the activities of geological prospecting organizations, whose "output" in the form of knowledge is classified as a "commodity" whether or not the prospecting leads to production of minerals $[39$, p. 22]. Finally, this school also asserts that only a very small share of applied R\&D might lack social use value because it is unsuccessful. According to studies of Soviet specialists, the desired results are obtained in $80-90$ percent of applied research and in 90-95 percent of development work [39, pp. 41-42].

(2) This school also rejects the argument that SNLC cannot be calculated for R\&D because it is nonrepetitive. They estimate the share of theoretical research at only $10-12$ percent of total outlays on science, and at merely 1-3 percent of total expenditures in industrial branch research institutes and design bureaus. Within applied R \& D, they hold, only one-third of the total involves truly creative nonrepetitive work with uncertain results, while two-thirds has precedents and analogs that permit the calculation of SNLC and cost norms. However, they suggest that the small amount of unsuccessful R\&D be excluded from such calculations $[39$, pp. $29-30 ; 53$, pp. 47-48; 19, p. 156;23, p. 141]. Finally, in regard to the truly original, nonrepetitive one-third of applied $R \& D$, they point out that lack of repetitiveness does not prevent the calculation of costs and the assignment of prices in the case of "unique" special-order material products like turbines and machine tools $[41$, p. 64].

(3) In regard to the "alienation" issue, some members of this school argue that all $R \& D$ qualifies as a "commodity" because it is created with the aim of transferring it to others (rather than retaining it in the $R \& D$ unit), as shown by the organizational and financial separation of $R \& D$ from material production. This is true for fundamental research financed by the budget and transferred to the use of society as a whole, as well as for contractual applied $\mathrm{R} \& \mathrm{D}$ for specific customers [19, pp. 146-147; 27, pp. 26-29].

However, a less extreme and more common view within this school is that applied $R \& D$ clearly fulfills all three requirements of a "commodity", but that fundamental research - though possessing (1) social use value - does not pass (2) the SNLC and (3) the alienation tests $[40$, p. $119 ; 19$, p. 154 ; 32, pp. 89-90]. Hence, they consider prices for applied R\&D appropriate on Marxian theoretical grounds, as well as necessary for several practical reasons of economic management.

The first reason is that the operation of an organization on an "economic accountability" basis should involve the sale of output in this case 
R \& D services - to customers at prices that cover costs and provide a profit, some of which is paid to the state budget and some of which is retained for bonuses, housing and recreational facilities, and expansion of production (i.e. R\&D) capabilities $[35$, p. $182 ; 19$, pp. $164-165 ; 32$, p. 76]. Also, when R\&D organizations are units in scientificproduction associations, the activities of the $R \& D$ organizations can be properly compared and aggregated with those of the producing enterprises only if the outputs of both types of member units are priced in the same way, i.e. to cover normative cost plus a normative profit [23, pp. 147-148].

Second, prices on $R \& D$ can be set so as to increase the incentives to the management and staff of R\&D organizations to choose projects with the greatest potential economic effect, to complete work with minimum cost on (or ahead of) schedule, and to achieve results of a high technical quality that are ready for application in production [51, p. 87].

Third, the undervaluation of $\mathrm{R} \& \mathrm{D}$ services transferred to customers at cost provides an unjustified subsidy to research-intensive kinds of material production. Instead, applied R \& D services should, like other nonlabor inputs, have explicit prices [18, pp. 172-173].

\subsubsection{How should applied $R \& D$ be priced?}

There are two basic proposed approaches (each with variants) to the pricing of applied $R \& D$ services. One approach - corresponding to the theoretical position that R\&D is an "actual" commodity - would set the price equal to planned cost plus a profit markup related to all or part of cost. The other - consistent with the view that $R \& D$ is only a "potential" commodity - would relate the profit markup above cost to the expected or achieved effect from the assimilation of $R \& D$ into production.

(a) Profit markup related to cost. Under this approach profit is deemed to be the value of "surplus product" created in applied R\&D itself, and the $R \& D$ organization receives the profit upon the sale of the $R \& D$ (or in part earlier as advance and progress payments).

One variant relates the profit markup to total planned cost of production. With $P$ representing price; $S$, planned cost; $\Pi$, planned profit (or profit plus turnover $(a x)$; and $a$, the percentage profit markup, $P=S+\Pi$, and $\Pi=a S$, so that $P=S+$ $a S$, or

$P=(1+a) S$.

There is no separate "branch" of applied R\&D for either organizational or accounting purposes. Instead, R\&D organizations are classified in the branches of the industrial ministries to which they belong. Hence, under this variant the profit normative $a$ would be based on the planned ratio of $\Pi$ to $S$ in the material production of the industrial enterprises of the branch. However, this ratio would be adjusted upward to allow for the greater complexity and difficulty of $\mathrm{R} \& \mathrm{D}$, compared to industrial output [23, pp. 143-145].

The other variant relates the profit markup only to the direct wage component of production cost, on the grounds that (present, not past) labor is the decisive input in $\mathrm{R} \& \mathrm{D}$, though not always in material production, and that the wage bill often constitutes close to half of total cost in $R \& D$, compared with 15-25 percent in much of material production. With $W$ representing planned wages, and $b$ the percentage profit markup, $P=S+\Pi$, and $\Pi=b W$, yielding

$P=S+b W$.

The profit coefficient $b=\Pi / W$ in $\mathrm{R} \& \mathrm{D}$ should exceed the corresponding ratio in material production of the branch, however. Because R\&D is more creative and more complex than industrial production, a ruble of wages is deemed to generate more surplus value (whose monetary reflection is profit) in the former than in the latter $[40, \mathrm{pp}$. 121-122].

R \& D performers prefer a profit markup related to the cost, rather than the economic effect, of R\&D. First, the R\&D unit gets the profit for adequately completing the project in accordance with the conditions of the contract - without any dependence on the outcome of the assimilation process. Second, the R\&D unit can increase profit by reducing actual cost below estimated cost. $R \& D$ performers claim this is an incentive to minimize costs [40, pp. 120-121].

However, critics of a profit markup related to planned cost point out that $\mathrm{R} \& \mathrm{D}$ performers would be motivated (1) to inflate estimated cost and thus profit as well, and (2) to reduce actual cost by lowering the quality of the work. Further, these critics argue that $R \& D$ performers should 
have a financial stake in the application of their results $[51$, pp. $83-85]$.

(b) Profit markup related to economic effect. In this approach to pricing $R \& D$ the profit component of the price would be a part of the (estimated or actual) monetary effect achieved from the successful assimilation of $R \& D$ into production, which would thus determine the amount of profit and the time of its receipt.

From a theoretical standpoint, economists who believe R\&D is only a "potential" commodity find this approach more acceptable than a profit markup related to cost. However, the chief justification is the financial incentive this approach creates for $R \& D$ units to produce high quality results on time and to aid in the assimilation process - two parts of the Soviet Government's effort to "link science with production" [17].

There are many rather similar variants of formulas to construct $R \& D$ prices with profit related to economic effect. The following representative formula, proposed by V.A. Pokrovskii, a department head at the USSR State Committee for Science and Technology and a leading Soviet science economist, illustrates the essential ideas. As before, $P, S$, and $\Pi$ stand, respectively, for price, planned cost, and planned profit. In addition, the following notation is used:

$f$, the share of the potential economic effect received by producers (rather than users) of the new technology incorporating the $\mathrm{R} \& \mathrm{D}$;

$d$, the particular R\&D organization's subshare of the producers' share $f$ (the balance of $f$ going to the industrial enterprise and any other R\&D performers);

$g$, the percentage probability that the potential economic effect will actually be achieved;

$E$, the potential economic effect.

Then $\Pi=d f g E$, so that

$P=S+d f g E$.

Pokrovskii further recommends that coefficients $d$, $f$, and $g$ be differentiated by industrial branches [35, pp. 181-182].

Advocates of this approach ditrer on the possible sources or components of the "economic effect" from the introduction of R\&D - and whether and how they could be measured. The types of economic effect suggested include the following:
(1) increase in profits due to reduction in current and capital costs of production; (2) increase in volume of output; (3) increase in labor productivity; (4) improvement in quality; (5) production of "fundamentally new" output; and (6) improvement of working conditions [39, pp. 83-84]. In addition, one must decide over how many producers and over what time period the economic effect will be calculated.

From the standpoint of the R\&D performer, a profit markup based on economic effect has drawbacks. First, the size of the effect depends heavily on the success of producing enterprises in assimilating $\mathrm{R} \& \mathrm{D}$, including their ability to build or reconstruct production facilities, to retrain workers, to obtain new materials, etc. Second, the $\mathrm{R} \& \mathrm{D}$ unit is likely to consider too small the share of the economic effect received by it - compared with the shares of the producing enterprise (and perhaps other R\&D performers) and the users. Third, the R\&D unit would receive its share with a considerable lag, since assimilation of $R \& D$ into mass production commonly takes two or more years. During this period, the R\&D organization would not have the money corresponding to its share available for bonuses and other uses. However, the last problem could be alleviated by paying some of the profit markup as an advance upon acceptance of the $R \& D$ and the balance when assimilation is successfully completed $[40, \mathrm{pp}$. $120-121 ; 27$, pp. $38-39 ; 23$, pp. $142-145$ ].

(c) Profit markup related to both cost and economic effect. Citing the advantages and disadvantages of the preceding two approaches, some Soviet science specialists recommend a compromise solution with profit composed of two components. One component, $\Pi_{c}$, would be related to cost and paid upon acceptance of the completed R\&D. The other component, $\Pi_{\mathrm{e}}$, would be related to the economic effect and paid after it is achieved. Let $P$ represent price; $S$, planned cost; $\hat{a}$, a percentage profit markup smaller than $a$ in formula (1) above; $f$, the share of the economic effect going to producers (R\&D performers and enterprises), rather than users; $\hat{d}$, a subshare of $f$ for the particular $\mathrm{R} \& \mathrm{D}$ performer, smaller than $d$ in formula (3) above; and $E^{\prime}$, the actual, rather than potential, economic effect. Then $P=S+\Pi, \Pi=\Pi_{\mathrm{c}}+\Pi_{\mathrm{c}}$, $\Pi_{\mathrm{c}}=\hat{a} S$, and $\Pi_{\mathrm{e}}=\hat{d} f E^{\prime}$, yielding

$P=(1+\hat{a}) S+\hat{d} f E^{\prime}$. 
Under this proposal, the first profit component, $\Pi_{c}$, should be sufficient to make minimum payments into the R\&D unit's funds for material incentives (individual bonuses), for housing and social-cultural measures, and for development of the organization's research capabilities. The second component, $\Pi_{\mathrm{e}}$, would provide additional money for these three purposes, as well as money for exploratory research, a reserve fund to cover losses from unsuccessful work and cost overruns, the expansion of working capital, and repayment of bank loans for capital investment [19, pp. 158-159; 32, pp. 91-93].

\subsection{Current practices}

There is no single official methodology for pricing applied R\&D services in the USSR at present. Instead, a number of methods are used, based on different proposals advanced in the theoretical debate. This subsection first explains the evolution of R\&D pricing over the last 20 years. Then it examines the information available on the relative importance of different pricing schemes.

The development of R\&D pricing in the USSR shows a growing acceptance of the inclusion of profit in price and the linking of profit to economic effect $[11 ; 26$, pp. 144-150].

From the late 1950 s, when contracting for R\&D was introduced, through 1967 applied R\&D was essentially priced at planned cost. However, the latter included bonus money, initially amounting to 3 percent of the wage fund and amounting in 1964 to 8-10 percent of it. Payment was by stages, terminating with the acceptance of finished $R \& D$ by the customer.

With $P, C$, and $S$ representing, respectively, the price, the estimate cost, and the planned cost of production, ${ }^{5}$ the pricing scheme was $P=C$ and $C-S$, yielding

$P=S$.

Profits in $R \& D$ were explicitly recognized in the March 22, 1967, Resolution of the USSR Council of Ministers, "On Changes in the Method of Planning Expenses on Scientific Research Work and on Expanding the Rights of Directors of

\footnotetext{
${ }^{5}$ Suviet costing and pricing practice distinguishes between the "cost of production" ( sebestoimost') and the "estimate cost" (smetnaia stoimost'). The latter may or may not include a profit above the cost of production.
}

Scientific Research Institutions". It gave R\&D organizations the right to retain 75 percent of the excess of planned over actual cost. The remaining 25 percent was to be paid to the state budget. The retained funds could be used to acquire materials and equipment to strengthen the organization's research capabilities. Thus, with $\Pi^{\prime}$ for actual profit, $S$ for planned cost, and $S^{\prime}$ for actual cost, the result was

$\Pi^{\prime}=0.75\left(S-S^{\prime}\right)$

The next step was to include in the price of R\&D a profit linked to the expected ("calculated" or "guaranteed") economic effect. This was authorized by the September 24, 1968, Party-Government Resolution, "On Measures to Increase the Effectiveness of Scientific Organizations and Speed Utilization in the National Economy of Achievements of Science and Technology". The estimate cost could now include a profit equal to not more than 1.5 percent of the annual economic effect guaranteed by the R\&D performer to the customer, up to a maximum of 6 percent of estimate cost, provided that the estimate cost did not exceed 50 percent of the guaranteed economic effect. Let $P, C, S, \Pi$, and $E$ represent, respectively, the price, the estimate cost, the planned production cost, the planned profit, and the guaranteed economic effect. Then $P=C, C=S+$ $\Pi$, and $\Pi=0.015 E$, subject to the restrictions $0.015 E \leq 0.06 C$ and $C \leq 0.5 E$. Hence

$P=S+0.015 E \quad(0.015 E \leq 0.06 C, C \leq 0.5 E)$.

In addition, the $R \& D$ performer could retain as profit 75 percent of the excess of planned cost over actual cost.

For some R\&D - such as the creation of new items for export and work to improve safety conditions - it is considered impossible to calculate the economic effect. In this instance, the price is set equal to planned cost, $S$, plus a planned profit, $\Pi$, of up to 20 percent of the wage fund of the R\&D personnel involved, $W[49, \mathrm{pp} .46-47]$. This is an application of the proposal in formula (2) above, with the restriction that the profit markup coefficient $b$ not exceed 0.2 . Hence, this pricing scheme is

$P=S+b W \quad(b \leq 0.2)$.

Other exceptions involve the output of test 
facilities and the provision of "production services" such as measurements, computing, and consultation on assimilation and production problems. In both cases, output is priced with a profit markup of up to 20 percent on cost [49, pp. $65-66 ; 39$, pp. 43-47]. This is an application of the scheme in formula (1) above, with the restriction that the profit normative $a$ not exceed 0.2 . Hence

$P=(1+a) S \quad(a \leq 0.2)$.

Advocates of relating profit to economic effect regarded the pricing formula in (7) as a step forward, but criticized the linking of profit only to the expected, rather than the achieved, economic effect. This problem is addressed by a pricing scheme adopted experimentally first in the USSR Ministry of the Electrical Equipment Industry and then in several other ministries. Under this scheme the price to the $R \& D$ performer includes one profit component related to the expected economic effect and another profit component linked to the actual economic effect.

Let $P$ stand for the price of $\mathrm{R} \& \mathrm{D} ; S$, its planned cost; $E$, the estimated economic effect; $h$, the $\mathrm{R} \& \mathrm{D}$ performer's share in $E ; E^{\prime}$, the actual economic effect; and $j$, the performer's share in $E^{\prime}$. Then the price is composed as follows:

$P=S+h E+j E^{\prime}$.

As explained further in section 4 , the economic effect is calculated differently for a new process that makes it possible to produce the same output at lower cost, and for a new product. For the former, the effect is the cost saving to the producing enterprise(s). For the latter, the effect is the combined saving in cost to both producers and users of the new product. For a particular new technology, either $h$ or $j$ might be zero, making the profit component of the price dependent only on the actual or the estimated effect.

Under formula (10), the R\&D unit can still obtain additional profits equal to the excess of its planned over its actual cost, and retain 75 percent of them.

According to Soviet science specialists, no statistics are regularly compiled on the portions of total applied R\&D priced by the various formulas in use, on the distribution of $\mathrm{R} \& \mathrm{D}$ performers' contract revenue among cost and profit, or on the shares of the different sources of profit. Instead, contemporary accounting in Soviet R\&D organizations concentrates on comparisons of planned and actual costs. These comparisons are used for the evaluation of (one aspect of) an $\mathrm{R} \& \mathrm{D}$ organization's performance and for the transfer to the state budget of 25 percent of the excess of planned over actual cost [35, p. 178].

To analyze the price structure of R \& D, special studies of samples of R\&D organizations are necessary, and a few have been reported in the scanty Soviet literature on pricing R \& D. One study of 25 R\&D units in the Ministry of the Electrical Equipment Industry was described by Fatova [11, pp. 70-71], although she did not disclose the kind and amount of $\mathrm{R} \& \mathrm{D}$ or the time period covered. In these R\&D organizations, 89 percent of revenue went to cover cost, leaving a profit equal to 11 percent. Of the total profit, 27 percent came from funds included in estimate cost (e.g. for profits planned in relation to wages or total cost); 55 percent from the excess of planned over actual cost; and only 18 percent from payments linked to economic effect. Further, of the profits linked to economic effect, 60 percent were based on the potential (estimated) effect and only 40 percent on the actual effect.

Broadly similar results were reported by Pokrovskii [35, p. 180] for a separate study of 19 research institutes in various branches of the economy, although he gave no information about which branches, the kind and amount of work, or the time period. According to this study, the share that actual cost absorbed of total revenue ranged from 79 to 94 percent, leaving a profit share of 6 to 21 percent. The difference between planned and actual cost was the main source of profit. This difference ranged from 3 to 15 percent of total revenue, while payments for economic effect provided only 2 to 6 percent of total revenue.

These and other studies, for example [19, pp. 165-166], conclude that economic effect payments are still a minor source of profit for $\mathrm{R} \& \mathrm{D}$ organizations. The bulk of their profits comes from the excess of planned cost over actual cost, resulting chiefly from the overstatement of the former. Also, only a minor share of the money for their incentive funds comes from payments for the actual economic effect of their work. 


\section{Incentive aspects of pricing applied research and development services}

The pricing of applied research and development services may have negative or positive incentive effects. As explained above, R\&D organizations are encouraged to increase planned costs when pricing relates profit to planned wages or total cost, or to the excess of planned over actual cost. In contrast, pricing schemes linked to economic effect seek to motivate R\&D organizations to deliver on time high quality results ready for assimilation into production. The chief mechanism for this purpose is payment of part of the economic effect to the R\&D organization's economic incentive funds. The R\&D performer thus has a clear financial stake in the economic effect of its work, because this effect influences its revenues and rewards to its personnel.

Subsection 4.1 examines how the economic effect is calculated and why the expected effect often exceeds the actual effect. Subsection 4.2 explains how incentive payments are linked to the economic effect and how these payments are distributed among $\mathrm{R} \& \mathrm{D}$ organizations and producing enterprises contributing to it. Subsection 4.3 analyzes the sources and uses of the three economic incentive funds of $R \& D$ organizations.

\subsection{Calculation of economic effect}

The current standard methods of calculating the economic effect of new technology were established in 1977 by agreement of the USSR State Committee for Science and Technology, the USSR State Planning Committee, the USSR Academy of Sciences, and the USSR State Committee for Inventions and Discoveries [30], replacing a methodology adopted in 1964 [34].

The basic formula for the economic effect of a new process or method of production that reduces the cost of producing the same output may be expressed with the following notation:

\footnotetext{
$E^{*}, \quad$ annual economic effect from introduction of a new process or method of production;

$C_{1}^{p}$ and $C_{2}^{p}$, producer's unit operating cost with the old ("base") and new processes, respectively;
}

$K_{1}^{p}$ and $K_{2}^{p}$, producer's unit capital investment with the old and new processes, respectively;

$r$ normative coefficient of effectiveness of capital $(r=0.15)$;

$N$ annual volume of output in physical units.

Then the economic effect of the new process is determined as the saving in "calculated costs" composed of current operating cost and notional capital cost (computed specially for this purpose but not included in enterprise cost accounts). Thus $E^{*}=\left[\left(C_{1}^{p}+r K_{1}^{p}\right)-\left(C_{2}^{p}+r K_{2}^{p}\right)\right] N$.

The formula for the economic effect of a new product, like a machine, that can replace an inferior existing "base" product selected for comparison is similar in principle but more complicated. The following notation will be used:
$\hat{E}$,
annual economic effect from the production and use of the new machine;
$C_{1}^{p}$ and $C_{2}^{p}$, producer's operating cost per unit of the base and new machines, respectively;
$r$ normative coefficient of effective- ness of capital $(r=0.15)$;
$K_{1}^{p}$ and $K_{2}^{p}$, producer's capital investment per unit of the base and new ma- chines, respectively;
$O_{1}$ and $O_{2}$, annual output in physical units from one unit of the base and new machines, respectively;
$A_{1}$ and $A_{2}$, amortization rate (equal to the inverse of the service life consid- ering obsolescence) for the base and new machines, respectively;
$K_{1}^{u}$ and $K_{2}^{u}$, user's capital investment for the base and new machines, respec- tively, for the amount of output produced with the new machine;
$C_{1}^{u}$ and $C_{2}^{u}$, user's annual operating cost to employ the base and new ma- chines, respectively;
$Q_{2}$, annual quantity of production of the new machine in physical units.

The economic effect is calculated as follows:

$$
\hat{E}=\left[\left(C_{1}^{p}+r K_{1}^{p}\right) \cdot \frac{O_{2}}{O_{1}} \cdot \frac{A_{1}+r}{A_{2}+r}\right.
$$




$$
\begin{aligned}
& +\frac{\left(C_{1}^{u}-C_{2}^{u}\right)-r\left(K_{2}^{u}-K_{1}^{u}\right)}{A_{2}+r} \\
& \left.-\left(C_{2}^{p}+r K_{2}^{p}\right)\right] Q_{2} .
\end{aligned}
$$

Thus, the annual economic effect for a new product depends on (1) the producer's "calculated costs" of making the base machine, adjusted for differences between the old and new machines in productivity and in service life allowing for a standard return on capital; (2) the user's saving in "calculated costs," adjusted for the service life of the new machine allowing for a standard return on capital; (3) the "calculated costs" to the producer of making the new machine; and (4) the quantity of the new machine produced. (For an example of the calculation of $\hat{E}$ for an actual new machine, see [23, pp. 70-72].)

The application of these formulas for calculating the economic effect involves a number of problems. They include the choice of the "base" process or product, the time period over which the effect should be calculated, the volume of output assumed, the number of users to be considered, the future costs of producers and users, and the degree of uncertainty to be acknowledged $[52 ; 12 ; 5 ; 24 ; 31]{ }^{6}$

Of particular relevance to this study is the common overestimation of the expected economic effect compared to the actual (achieved) effect calculated according to the same formula. One investigation reported by a leading Soviet science economist covered $113 \mathrm{R} \& \mathrm{D}$ projects in 19 research institutes in different branches, although the branches and the time period are not mentioned. The actual effect was less than the planned effect for 56 percent of the projects; the two effects were approximately equal for 28 percent; and the actual effect exceeded the planned effect for only 16 percent [35, p. 66]. Another survey of an unspecified set of Moscow R\&D organizations found that expected effects were often triple the corresponding actual effects $[5, p .51]$. The most common errors are underestimation of the operating and capital costs of producers and users of new machines, and overestimation of the quantity

\footnotetext{
6 Also, the formula for the economic effect of a new product is addressed to capital goods and there is no corresponding method for assessing the economic effect of a new consumer good.
}

of new machines to be produced - respectively, $C_{2}^{p}, K_{2}^{p}, C_{2}^{u}, K_{2}^{u}$, and $Q_{2}$ in eq. (12) [26, p. 83; 50, p. 44].

There are several types of reasons for the overstatement of the expected economic effect.

First, some calculations of expected effect are unintentionally inaccurate. Sometimes correct basic data for the various terms in eq. (12) are not used in the calculation of the economic effect. They may exist but not be available to the $R \& D$ organization's economists performing the calculation, or they may not be collected at all in the proper form (for instance, for user costs for individual machines) [42, pp. 97-98]. Also, the calculation is sometimes done by unqualified personnel, or without the computer services necessary to handle properly the amount of data and computations involved [51, pp. 121-125]. In addition, the inherent uncertainty of R\&D is a source of inaccuracy, although the extent of error justifiably attributable to uncertainty depends on factors such as the novelty of the project, the stage of work (research versus development), and the size of the effect [50, pp. 44-46].

Second, the R\&D organization has an incentive to overstate the expected economic effect in order to undertake more (especially, large and prestigious) projects [50, p. 42] and to receive revenue based on the expected effect and included in the estimate cost of the project, at least as an advance against the actual effect [46, p. 73].

Third, the actual effect is often less than it should be, because producing enterprises fail to assimilate R\&D into production as quickly and thoroughly as they could. At the enterprise, the material incentives are stronger for good performance on sales, profit, and other current production indicators than for innovation, which tends to conflict with current production [35, pp. 143-145].

\subsection{Incentive payments linked to economic effect}

For the purpose of linking payments to economic incentive funds of enterprises and $R \& D$ organizations to the economic effect of new technology, Soviet regulations distinguish five categories of new technology [36]:

(1) new process technology whose economic effect $\left(E^{*}\right)$ occurs in a reduction in production costs and is reflected in additional profits to the producer(s); 
(2) new product technology whose economic effect $(\hat{E})$ occurs in the production of new high quality products and is reflected in additional profits to the producer(s) from surcharges in the industrial wholesale prices of the products;

(3) new technology for complex systems of machinery and equipment whose economic effect can be measured but is not reflected in additional profits to producers from cost reductions or price surcharges;

(4) new technology with a measurable economic effect developed for other ministries; and

(5) new technology whose economic effect cannot be calculated - including technology for production of exports or import-substitutes, for product standards, for environmental protection, for improving product reliability, for scientific information, and for management systems.

In the case of category (1), a portion of the additional profits of the producer(s) over a designated period - initially two years, now three years - is devoted to incentive payments. The portion varies by ministry. For example, it is 15 percent in the Ministry of the Electrical Equipment Industry and 16.5 percent in the Ministry of Heavy and Transport Machine Building [32, p. 103].

In the case of category (2), incentive payments come from the additional profits of producers due to surcharges in the industrial wholesale prices. These surcharges make the profitability rate (in relation to production cost) of the new products 50 to 125 percent higher than the standard profitability norm for that category of output. The surcharges may be authorized for up to five years by the State Committee on Prices. Up to 70 percent of the additional profit from these surcharges can be allocated to incentive payments. The ministry and the state budget each receive at least 15 percent [28, pp. 131-133].

The amount of money allocated to incentive payments out of additional profits from the price surcharge for a particular product is determined by a schedule for each ministry that relates the amount of incentive payments to the economic effect. These schedules are regressive; i.e. incentive payments are a smaller percentage of the economic effect, the greater the effect [32, p. 115].

For categories (3) and (4) the customer makes incentive payments in amounts established in special regulations as shares of the annual economic effect guaranteed by the organization (and subject to adjustment upon acceptance of the completed results).

For category (5), when the economic effect is not calculated, incentive payments are instead related to the wages of the personnel directly involved, in amounts up to 20 percent of their wage bill.

The incentive payments for categories (1) and (2) are normally made after the additional profits are actually earned, while the incentive payments for categories (3), (4), and (5) are included in the estimate cost of the work.

When the planned period for the development and assimilation of the new technology exceeds two years, advances of up to 30 percent can be made against expected incentive payments.

After the amounts to be allocated for incentive payments are calculated, 20 percent is taken for the ministry's centralized bonus fund and 80 percent is shared among the institutes, design bureaus, experimental plants, and enterprises contributing to the creation and introduction of the new technology.

The ministry's centralized bonus fund provides bonuses for exceptional results in the five categories of new technology listed above; for fundamental, theoretical, and exploratory research; and for good performance on other aspects of the organization's activities (see subsection 4.3).

The "decentralized" 80 percent of incentive payments linked to the economic effect of a particular new technology is supposed to be distributed among institutes, design bureaus, and enterprises in the light of their respective contributions to this effect. The general guidelines for the distribution of the decentralized portion distinguish three stages in the creation and introduction of new technology: (1) research and development, (2) technological work and preparation for new production, and (3) assimilation of new technology in production. Formerly, the suggested ranges for the percentage shares for these stages were, respectively, 30-50, $20-25$, and $25-40$. In 1980, the respective ranges were changed to $20-40,20-40$, and $30-50$.

However, such ranges are only very broad recommendations. For each project the cooperating organizations negotiate their shares, which are included in the corresponding work-orders and contracts. These shares are supposed to be determined according to the amount, kind, complex- 
ity, and creativity of the work of each organization. But there are no generally agreed methods of measuring these characteristics in uniform ways for all participating organizations [14, pp. 49-50]. Instead, in practice shares are usually based on the organizations' respective total costs or, more commonly, labor costs for the project $[39$, p. $84 ; 3$, pp. 106-107]. ${ }^{7}$

No comprehensive statistics have been published about the shares in total incentive payments actually received by organizations at each of the three stages. Data for the Ministry of the Electrical Equipment Industry in 1978 show that organizations in research and development (stage 1) received 22.1 percent of the incentive payments from additional profits due to cost reductions from new processes and 59.9 percent of the payments from additional profits due to price surcharges on new products. The combined shares of stages 2 and 3 (preparation and assimilation) were 77.9 and 40.1 percent for process and product innovation, respectively [23, p. 116]. However, these shares for the R\&D stage for these categories of new technology may vary considerably by ministries because of differences in the nature of their output and in relative labor costs at different stages in the research-development-innovation cycle.

\subsection{Sources and uses of economic incentive funds}

The impact on $\mathrm{R} \& \mathrm{D}$ organizations and their performance from incentive payments linked to economic effect depends both upon the relative importance of these payments as a source of money for incentive funds, and also upon the uses of these incentive funds. This subsection analyzes the sources and uses of each of the three economic incentive funds of Soviet applied R\&D organizations.

\footnotetext{
7 Labor cost is the basis favored by many Soviet specialists on the theoretical ground that (current) labor is the chief factor in the creation of new technology and on the practical ground that most of the material incentive fund, the largest of the three economic incentive funds, is usually distributed among an organization's personnel proportionally to wages. However, some advocates of labor cost as the basis for sharing incentive payments urge that, for such calculations, wage bills are imperfect measures of true labor inputs and should be adjusted for differences across coperformers in the originality, productivity, and other aspects of labor not fully reflected in relative wages $[2$, pp. 94-98; 45].
}

\subsection{Organization Development Fund (ODF)}

There are five sources of money for the ODF [36; 32, pp. 114-116]:

(1) 75 percent of the excess of planned over actual costs on contract and work-order projects, with the calculation of costs in both cases excluding incentive payments included in estimate costs;

(2) funds included in the estimate costs of projects done on contracts or work-orders, in an amount equal to 1.5 percent of the guaranteed annual economic effect, but not more than 6 percent of the estimate cost, which cannot exceed 50 percent of the effect;

(3) 10 percent of the incentive payments to the organization for its share of additional profits from price surcharges on new products;

(4) revenue from the sale of licenses; and

(5) proceeds from the sale of excess equipment.

The prescribed uses of the ODF are acquisition of equipment and materials, financing capital investments, and repayment of State Bank loans for investment purposes [32, p. 117].

In practice, 75-90 percent of the money accruing to R \& D organizations' ODFs comes from cost savings (source 1 above), which supervising agencies consider to be due chiefly to the inflation of planned cost. Therefore, ministries commonly confiscate the bulk of the funds accruing to the ODF and use them instead for scheduled increases in the unit's working (not fixed) capital. For example, 86 percent of the ODF money in the Ministry of the Electrical Equipment Industry in 1975 was redirected in this way [26, p. 160].

\subsubsection{Social-Cultural Measures and Housing Con- struction Fund (SCHF)}

The SCHF receives 30 percent of the $R \& D$ organization's incentive payments from producers' additional profits from new product technology (category 2 in subsection 4.2 above), and 40 percent of its incentive payments for the other categories of new technology [36].

The SCHF is used to construct, repair, and operate housing, nurseries, clinics, recreational facilities, and food service establishments for the personnel of the organization.

\subsubsection{Material Incentive Fund (MIF)}

The R\&D organization's MIF receives (1) 60 percent of the incentive payments for the five 
categories of new technology (2) payments from its ministry's centralized bonus fund; (3) payments from other ministries for work on contracts with them; and (4) payments from temporary price surcharges on consumer goods, prizes in competitions, and many other sources [36].

No comprehensive statistics are published on the size of the MIF (or SCHF) in relation to the wage fund in R\&D organizations. However, in 1974-77 the ratio of the MIF to the wage fund in research institutes and design bureaus averaged 18.7 percent in the Ministry of the Electrical Equipment Industry and 16.9 percent in the Ministry of Heavy and Transport Machine Building [32, p. 122].

Some Soviet specialists consider these percentage relationships reasonable but point to a wide variance among $R \& D$ organizations around the average figures. For example, in the Ministry of the Electrical Equipment Industry the ratio in 1974-1977 ranged from 3 to 30 percent because of the kind of work done by the organization and the relative importance of different sources of money for the MIF [32, p. 122].

Only sparse and noncomparable data have been published about the shares of different sources in the MIFs of $R \& D$ organizations. Table 1 presents relevant statistics for the Ministry of the Electrical Equipment Industry and the Ministry of Power Machine Building. In the former ministry, of total payments to MIFs of research institutes and design bureaus, about a fourth came from the ministry's centralized bonus fund and about a third from other sources, whereas these two categories were of negligible importance in the latter ministry. However, in both ministries the combined shares of payments linked to actual economic effects in the form of additional profits from new processes and from new products (the first two rows in table 1) were comparatively small - approximately one-third in electrical equipment and one-fourth in power machine building. ${ }^{8}$

Thus some Soviet specialists urge raising the rclative importance of the two sources related to economic effect - and perhaps thereby also the absolute amount of MIFs - by two changes. One is augmentation of the coefficients for the fraction of additional profits from new technology devoted to incentive payments (see subsection 4.2). The other is increasing the share of these payments allocated to $\mathrm{R} \& \mathrm{D}$ organizations, and decreasing the share for producing enterprises, whose bonus funds in any case depend chiefly on performance regarding sales, profit, labor productivity, and other aspects of current production [23, pp. 120-121].

However, the incentive effects of the MIF depend not only on its size and origins but also on its distribution, including the criteria for good performance and the extent to which they are applied in practice.

According to official regulations, an $R \& D$ organization's MIF can be used for (1) bonuses for creation of new technology; (2) bonuses for fulfillment of the quarterly project plan; (3) bonuses for

8 The different proportions of the various sources in the two ministries may be related to differences in the nature of their output - for example, more large production runs in electrical equipment versus more special-order and small batch products in power machine building.

Table 1

Percentage shares of sources of material incentive funds of research institutes and design bureaus: Ministry of the Electrical Equipment Industry, 1979, and Ministry of Power Machine Building, 1978

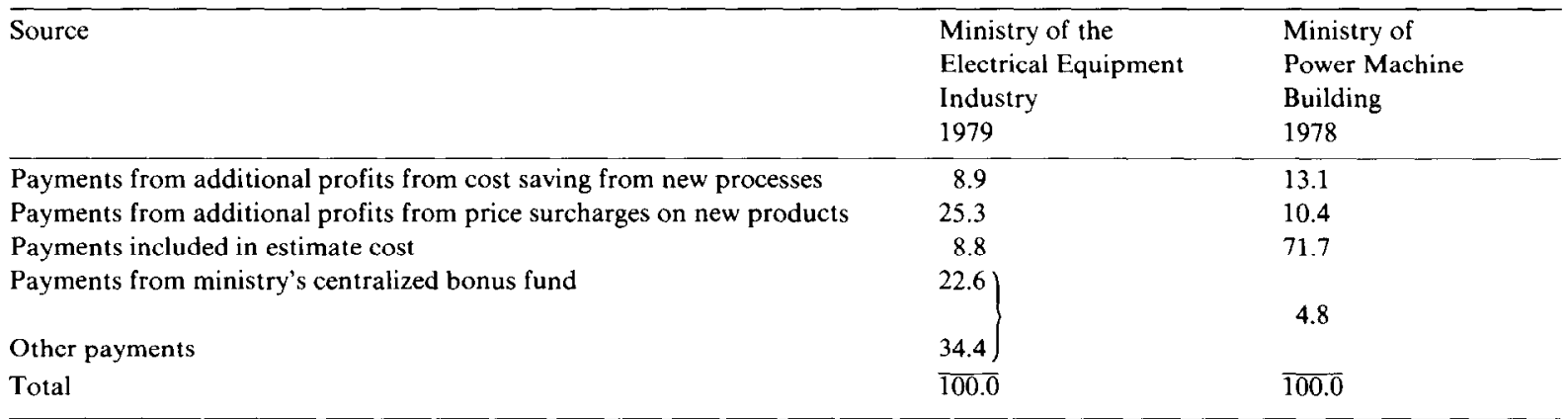

Source: $[46$, p. 76$]$. 
fulfillment of "especially important tasks"; (4) bonuses for the overall results of the organization for the year; (5) bonuses for results in competitions; (6) bonuses for "other work accomplishments"; and (7) miscellaneous payments, such as vacation allowances for workers in remote locations.

Thus, the extent of the contribution to the economic effect of new technology is only one of many criteria for the distribution of bonus money.

This is turn reflects the fact that the economic effect of R\&D is only one of many indicators by which the performance of an $R \& D$ organization is evaluated by superior agencies, and probably by the personnel of the organization itself. Of equal or greater importance compared to economic effect are two other sets of performance indicators. One set involves the fulfillment of the various elements of the organization's plan, including the amount of work done; the timeliness of its completion; its cost; and the use of the organization's resources of labor, materials, and equipment. The second set of indicators concerns the "quality" ("scientific-technical level") of the organization's work in terms of originality, theoretical sophistication, experimental verification, and other aspects $[25$, ch. $3 ; 9 ; 47$, ch. $2 ; 37 ; 44]$.

Thus three kinds of indicators are used in superior agencies' evaluation of the R\&D organization's activities. These indicators presumably should in turn guide the management of the R\&D organization in distributing bonuses to its personnel. Official regulations state that personal bonuses should be differentiated by a comparative evaluation of individual contributions, but there are no methodological instructions on how to do so [38, p. 114]. The problem is not the lack but rather the abundance of ways to evaluate individual contributions. Over 100 criteria have been proposed by Soviet specialists, including the amount of time devoted, initiative, creativity, responsibility, promptness, and completeness [22, p. 120].

In practice, bonuses are of ten paid to all personnel in a uniform proportion to their salaries [43, p. $217 ; 32$, p. 123$]$. A person's salary in turn ordinarily is based on position, scientific degree, and length of service, rather than the importance, quantity, and quality of current work. Hence, bonuses tend to be regarded, by the management and the personnel of the R\&D organization, as a proportional supplement to basic salary rather than a differentiated reward for better work [26, pp. 199 201].

\section{Conclusions}

The proper relationship of price to cost for $R \& D$ services has been the subject of an extended debate among Soviet science cconomists. The evolution of pricing of applied R\&D over the last 20 years shows a growing acceptance of the inclusion of profit in price and the linking of profit to economic effect.

In principle the linking of incentive payments to R\&D organizations to the economic effect of their work creates incentives for timely delivery of high quality results suitable for assimilation into production. ${ }^{9}$ However, the strength of these incentives is in practice diluted (1) by the relation of a large part of incentive payments not to the actual but to the (often inflated) expected effect; (2) by the size of the coefficients for the portion of the effect devoted to incentive payments; (3) by the distribution of total incentive payments between the ministry and the organizations contributing to the effect, and among these organizations; and (4) by the relative importance of different sources and uses of R\&D units' economic incentive funds.

\section{References}

[1] S.I. Aivazian, Iu.A. Vedeneev and O.A. Supataeva, Pravovye voprosy upravleniia nauchnymi issledovaniiami [Legal questions of the administration of scientific research] (Nauka, Moscow, 1980).

[2] A.Sh. Akhmeduev, Material'noe stimulirovanie tekhnicheskogo progressa v promyshlennosti [Material stimulation of technological progress in industry] (Nauka, Moscow, 1980).

[3] L. Andrukhovich and A. Zviagin, Raspredelenie ekonomicheskogo effekta of vnedreniia rezul'tator NIR i OKR mezhdu organizatsiami-soispolniteliami [Distribution of the economic effect from the introduction of results of R\&D among coperforming organizations], Planovoe khoziastvo 11 (Nov. 1979) 106-109.

[4] V.N. Arkhangel'skii, Planirovanie i finansirovanie nauch-

${ }^{9}$ In the United States incentive pricing schemes for R\&D are used chiefly in government ... especially military - procurement. But the incentives involved are primarily for cost-reduction, rather than for enhancing the effect from the application of the results. 
nykh issledovanii [Planning and financing of scientific research] (Finansy, Moscow, 1976).

[5] V.N. Arkhangel'skii, Metodicheskii podkhod k planirovaniiu ekonomicheskogo effekta NIOKR [Methodological approach to planning the economic effect of R\&D], Izvestiia Akademii Nauk SSSR, Seriia ekonomicheskaia 5 (Nov./Dec. 1980)50-58.

[6] A.F. Ashanina, Finansirovanie nauchnykh issledovanii za schet postuplenii po khozdogovoram [Financing of scientific research from contract revenues], Finansy SSSR 10 (Oct. 1980) 34-38.

[7] V. Babak, V. Logachev, and V. Dvorishin, Vazhneishie puti uskoreniia razrabotok novoi tekhniki [The most important ways of speeding development of new technology], Planovoe khoziaistvo 10 (Oct. 1980) 70-75.

[8] M.L. Bashin, Planirovanie nauchno-issledovatel'skikh $i$ opytno-konstruktorskikh rabot [Planning of scientific-research and test-design work], second, revised and enlarged edition (Ekonomika, Moscow, 1969).

[9] N. Dobretsova, O sisteme statisticheskikh pokazatelei rezul'tatov deiatel'nosti NII i KB [On the system of statistical indicators of the results of the activity of scientific research institutes and design bureaus], Vestnik statistiki 9 (Sept. 1980) 7-13.

[10] V. Ia. El'meev, E.F. Denisov, and S.F. Zotov, Ekonomicheskie usloviia soedineniia nauki s proizvodstvom [Fconomic conditions of uniting science with production], Izvestiia Akademii Nauk SSSR, Seriia ekonomicheskaia, 3 (May/June 1976) 55-66.

[11] L. Fatova, $O$ modeli dogovornykh tsen na nauchno-teknicheskie razrabotki [On the model of contract prices on scientific-technical developments], Planovoe khoziaistvo 1 (Jan. 1974) 67-74.

[12] V. Fel'zenbaum, Sovershentvovat' metody opredeleniia effektivnosti novoi tekhniki [To improve methods of determining the effectiveness of new technology], Voprosy ekonomiki 12 (Dec. 1978) 106-109.

[13] L.Ia. Gervits and O.A. Supataeva, Pravovye voprosy finansirovaniia nauchnykh issledovanii [Legal questions of the financing of scientific research]. Izvestiia Akademii Nauk SSSR, Seriia ekonomicheskaia 6 (Nov./Dec. 1978) 58-68.

[14] S. Golosovskii, Effektivnost' issledovanii i razrabotok [Effectiveness of research and development], Voprosy ekonomiki 10 (Oct. 1980) 46-53.

[15] G.V. Gromova, Material'no-tekhnicheskoe obespechenie nauki [Material-technical supply of science], Voprosy ekonomiki 3 (March 1978) 101-108.

[16] G.V. Gromova and E.V. Zharenkov, Planirovanie material'no-tekhnicheskogo obespecheniia issledovanii $\mathrm{i}$ razrabotok [Planning of material-technical supply of research and development]. in Upravlenie razvitiem nauki $i$ tekhniki [Administration of the development of science and technology] (Ekonomika, Moscow, 1980).

[17] M.A. Gusakov, Effektivnaia arganizatsiia protsessa "issledovanie - proizvodstvo" (Effective organization of the process "science-production"] (Ekonomika, Moscow, 1978).

[18] Iu. V. Iakovets, Tseny v planovom khoziaistve [Prices in a planned economy] (Ekonomika, Moscow, 1974).

[19] G.K. Iuzifovich and I.G. Zverev, Problemy ispol'zovaniia i tendentsii razvitiia stoimostnykh otnoshenii i khoziaistven- nogo rascheta $v$ sisteme upravleniia nauchnymi issledovaniami i razrabotkami [Problems of the utilization and tendencies in the development of value relationships and economic accountability in the system of administration of scientific research and development], in Tovarno-denezhnye otnosheniia $v$ usloviakh razvitogo sotsializma: tendentsii $i$ zakonomernosti [Commodity-money relations in conditions of developed socialism: tendencies and patterns] (Izd. Leningradskogo universiteta, Leningrad, 1979).

[20] S.G. Kara-Murza, Problemy organizatsii nauchnykh issledovanii [Problems of the organization of scientific research] (Nauka, Moscow, 1981).

[21] K. Kedrova, Finansovoe obespechenie nauchno-tekhnicheskogo razvitiia otrasli [Financial provision for the scientific and technical development of the branch], Voprosy ekonomiki 8 (Aug. 1980) 31-39.

[22] E.I. Kissel', Organizatsiia truda i upravleniia $v$ NII $i \mathrm{~KB} v$ usloviakh NTR [Organization of labor and administration in scientific research institutes and design bureaus in conditions of the scientific and technical revolution] (Ekonomika, Moscow, 1979).

[23] V.P. Kochikian, V.I. Koshkin and Ia. G. Liubinetskii, Kompleksnaia sistema stimulirovaniia tekhnicheskogo progressa [The complex system of stimulating technological progress] (Mysl', Moscow, 1980).

[24] A. Koshuta, Kriterii otsenki effektivnosti novoi tekhniki [Criteria of evaluation of effectiveness of new technology], Voprosy ekonomiki 2 (Feb. 1980) 56-66.

[25] R.A. Kozhevnikov, Ekonomicheskii analiz $i$ otsenka deiatel'nosti oraslevykh $N I I$ i $K B$ [Economic analysis and evaluation of the activity of branch scientific research institutes and design bureaus] (Sovetskoe radio, Moscow, 1979).

[26] G.A. Lakhtin, Ekonomika nauchnogo uchrezhdeniia [Economics of the scientific institution] (Ekonomika, Moscow, 1979).

[27] I.N. Lazarev, Finansirovanie nauchno-teknicheskogo progressa [Financing of scientific-technical progress] (Finansy, Moscow, 1980).

[28] A.M. Litiagina, Razvitie sistemy metodov upravleniia $v$ sfere nauki $i$ tekhniki [Development of the system of methods of administration in the sphere of science and technology], in Upravlenie razvitiem nauki i tekhniki [Administration of the development of science and technology] (Ekonomika, Moscow, 1980).

[29] M.I. Matuzon, Ekonomicheskie metody intensifikatsii deiatel'nosti NII i KB v mashinostroenii [Economic methods of intensifying the activity of scientific research institutes and design bureaus in machine building] (Mashinostroenie, Leningradskoe otdelenie, Leningrad, 1979).

[30] Metodika (osnovnye polozheniia) opredeleniia ekonomicheskoi effektivnosti ispol'zovaniia $v$ narodnom khoziaistve novoi tekhniki, izobretenii i ratsionalizatorskikh predlozhenii [Methods (basic principles) for determining the economic effectiveness of the use in the national economy of new technology, inventions, and innovative proposals], February 14, 1977, Ekonomicheskaia gazeta 10 (March 1977) 11-14.

[31] N. Miloslavskii, O edinykh osnovakh opredeleniia ekonomicheskoi effektivnosti novoi tekhniki i kapital'nykh vlozhenii [On unified bases for determining the economic 
effectiveness of new technology and capital investments], Voprosy ekonomiki 9 (Sept. 1980) 119-128.

[32] B.D. Motorygin and P.A. Sedlov, Ekonomicheskie problemy sozdaniia novo tekhniki [Economic problems of creating new technology] (Mashinostroenie, Moscow, 1980).

[33] L.E. Nolting, The Financing of Research, Development, and Innovation in the U.S.S.R., by Type of Performer, U.S. Department of Commerce Foreign Economic Reports, no. 9 (U.S. Government Printing Office, Washington, D.C., 1976).

[34] Osnovnye metodicheskie polozheniia po opredeleniiu ekonomicheskoi effektivnosti nauchno-issledovatel'skikh rabot [Basic methodological principles for determining the economic effect of scientific research work] (Ekonomika. Moscow, 1964).

[35] V.A. Pokrovskii, Povyshenie effektivnosti nauchnvk issledovanii i razrabotok (voprosy teorii) [Increasing the effectiveness of scientific research and development (questions of theory)] (Ekonomika, Moscow, 1978).

[36] Polozhenie o poriadke obrazovaniia i ispol'zovaniia fondov ekonomicheskogo stimulirovaniia $\mathrm{v}$ nauchno-issledovatel'skikh, konstruktorskikh, proektno-konstruktorskikh i tekhnologicheskikh organizatsiakh, proizvodstvennykh ob"edineniakh i predpriatiakh, perevedennykh na khozraschetnuiu sistemu organizatsii rabot po sozdaniu, osvoeniu i vnedreniu novoi tekhniki na osnove zakazovnariadov (dogovorov) [Statute on the procedure for formation and utilization of economic incentive funds in scientific-research, design, project-design and technological organizations, production associations and enterprises transferred to the economic accountability system of organization of projects for the creation, assimilation and introduction of new technology on the basis of work-orders (contracts)], April 10, 1980, Ekonomicheskaia gazeta 22 (May 1980) 11-14.

[37] K.F. Puzynia, Soderzhanie i funktsionirovanie sistemy upravleniia kachestvom $v$ nauchno-tekhnicheskikh organizatsiakh [Content and functioning of a system of administration of quality in scientific-technical organizations], in Organizatsiia promyshlennykh issledovanii i razrabotok novoi tekhniki [Organization of industrial research and development of new technology] (Lenizdat, Leningrad, 1978).

[38] V. Rakoti, Ob uchete lichnogo vklada pri premirovanii za sozdanie i vnedrenie novoi tekhniki [On the calculation of an individual contribution in awarding bonuses for the creation and introduction of new technology], Sotsialisticheskii trud 9 (Sept. 1979) 114-116.

[39] L. Rozhneva, Osobennosti tsenoobrazovaniia na produktsiu prikladnykh issledovanii $i$ razrabotok [Special features of price formation on the output of scientific research and development] (Izd. Leningradskogo universiteta, Leningrad, 1974).

[40] L. Rozhneva, Tsenoobrazovanie na produktsiu prikladnykh issledovanii $\mathrm{i}$ razrabotok [Price formation on the output of applied research and development], Voprosy. ekonomiki 3 (March 1977) 118-123.
[41] L. Rozhneva, $\mathrm{K}$ voprosu o kharaktere produktsii nauchno-teknicheskoi deiatel'nosti [On the question of the character of output of scientific-technical activity]. Ekonomicheskie nauki 12 (Dec. 1979) 63-68.

[42] A.A. Rumiantsev, Ekonomicheskaia otsenka NIR i OKR [Economic evaluation of R\&D] (Ekonomika, Moscow, 1978).

[43] P.A. Sedlov, Sovershenstvovanie material'nogo stimulirovaniia issledovatelei i razrabotchikov [Improvement of material incentives for researchers and developers], in $U p$ ravlenie issledovaniami, razrabotkami $i$ vnedreniem novoi tekhniki [Administration of research, development and the introduction of new technology] (Ekonomika. Moscow. 1977).

[44] P.A. Sedlov, Metody otsenki deiatel'nosti otraslevykh NII i KB [Methods of evaluating the activity of branch scientific research institutes and design bureaus], in Upravlenie razvitiem nauki i tekhniki [Administration of the development of science and technology] (Ekonomika, Moscow, 1980).

[45] A. Seleznev and E. Suvorov, Metod raspredeleniia fondov pooshchreniia mezhdu razrabotchikami novoi tekhniki [Method of distribution of incentive funds among developers of new technology]. Planovoe khoziaistvo 3 (March 1978) 133-135.

[46] V. Shalimov, Formirovanie sredsty material'nogo pooshchreniia za novuiu tekhniku [Formation of means of material incentives for new technology], Planovoe khoziaistwo 6 (June 1981) 71-79.

[47] I.V. Shul'gina, Analiz khoziaistwennoi deiatel'nosti NII [Analysis of the economic activity of scientific research institutes] (Finansy, Moscow, 1977).

[48] I.V. Shul'gina, Nakladnye raskhody $v$ strukture zatrat na nauku [Overhead expenditures in the structure of expenses on science], Finansy SSSR 7 (July 1978) 34-37.

[49] Sovershenstvovanie planirovaniia i ekonomicheskogo stimulirovaniia nauchno-tekhnicheskogo progressa [Improvement of planning and economic stimulation of scientific-technical progress] (Izd. Moskovskogo universiteta, Moscow, 1977).

[50] L. Veger, Garantirovannyi ekonomicheskii effekt NIOKR [Guaranteed economic effect of R\&D], Izvestiia Akademii Nauk SSSR, Seriia ekonomicheskaia 2 (March/April 1980) $42-50$.

[51] L. Veger and Iu. Matevosov, Tsenoobrazovanie v sfere nauchno-tekhnicheskoi deiatel'nosti [Price formation in the sphere of scientific-technical activity], Planovoe khoziaistvo 9 (Sept. 1977) 80-87.

[52] B. Zaitsev, Opredelenie effektivnosti tekhnicheskikh novshestv [Determining the effectiveness of technical innovations], Voprosy ekonomiki 10 (Oct. 1977) 93-103.

[53] G.J. Zhil'tsov, Osobennosti ispol'zovaniia khozraschetnykh otnoshenii $v$ sfere nauchnoi deiatel'nosti [Special features of the utilization of economic-accountability relations in the sphere of scientific activity], Izvestiia Akademii Nauk SSSR, Seriia ekonomicheskaia 4 (July/Aug. 1979) 40-49. 